\title{
Agriculture and Brexit Britain's 'No-deal' tariff plans
}

Article

Accepted Version

Swinbank, A. (2019) Agriculture and Brexit Britain's 'No-deal' tariff plans. EuroChoices, 18 (3). pp. 4-9. ISSN 1478-0917 doi: https://doi.org/10.1111/1746-692X.12244 Available at https://centaur.reading.ac.uk/88154/

It is advisable to refer to the publisher's version if you intend to cite from the work. See Guidance on citing.

To link to this article DOI: http://dx.doi.org/10.1111/1746-692X.12244

Publisher: Wiley

All outputs in CentAUR are protected by Intellectual Property Rights law, including copyright law. Copyright and IPR is retained by the creators or other copyright holders. Terms and conditions for use of this material are defined in the End User Agreement.

\section{www.reading.ac.uk/centaur}

\section{CentAUR}

Central Archive at the University of Reading

Reading's research outputs online 


\title{
Agriculture and Brexit Britain's ‘No-deal’ Tariff Plans
}

\begin{abstract}
Alan Swinbank
As this journal goes to press, the Brexit drama grumbles on. On 24 July 2019 Boris Johnson displaced Theresa May as Prime Minister, sacked most of her cabinet, and declared his absolute determination that the United Kingdom of Great Britain and Northern Ireland (the UK) would leave the European Union (EU) on 31 October 2019, with or without a deal. Johnson did, in fact, negotiate a revised deal, which was endorsed by the European Council on 17 October. This consisted of the Withdrawal Agreement negotiated by Mrs May, which provides for a transition (or standstill) period until the end of 2020. Appended is a revised Protocol on Ireland/Northern Ireland, which would lock Northern Ireland into the EU's Single Market for agri-food and other goods and, effectively, into its Customs union, for a further six year. In addition a Political Declaration asserts that the EU and the UK are resolved to negotiate 'an ambitious, broad, deep and flexible partnership across trade and economic cooperation with a comprehensive and balanced Free Trade Agreement at its core ...', during the transition period (GOV.UK, 2019c). There is though no guarantee that a Free Trade Agreement can be successfully negotiated.
\end{abstract}

Two days later Johnson's plans were thwarted by the UK's House of Commons, which refused to approve the withdrawal package until the necessary legislation enacting the Withdrawal Agreement had been adopted into UK law. The European Union (Withdrawal Agreement) Bill 2019-20 was introduced (House of Commons, 2019), but then left in limbo. How this latest impasse will be resolved is unclear at the time of writing: the EU has agreed an extension of the transition period to 31 January 2020, and the UK is embarked on a General Election on 12 December. However, the purpose of this article is not to document these recent events, analyse the new package and its compatibility with WTO trade rules, or to second-guess future developments. Instead it reflects on one key proposal that had emerged during the course of 2019 that is still potentially in play: the tariffs the UK announced it would apply in the event of a 'no-deal' Brexit. 
The UK had suggested that in the event of a 'no-deal' Brexit it would sweep away border protection on agri-food products, in rather sharp contrast to the EU's tariff regime for CAP (common agricultural policy) products, and despite mounting concern about the potential impact of a 'no-deal' Brexit on UK farmers. This article sets out to explore some of the political economy issues raised.

\section{Brexit Britain's tariff barriers}

In July 2018 the UK notified the WTO of its draft Schedule of Commitments, including: the tariff bindings (i.e. maximum tariff rates) by which it considered it would be bound; the tariff rate quota (TRQ) commitments it felt obliged to assume; the level of amber box (trade-distorting) support to which it felt entitled (at €5.9 billion per annum); and - following the WTO Ministerial decisions at Nairobi in 2015 - a commitment not to subsidise its agri-food exports (WTO, 2019). (For an explanation of tariff bindings, TRQs, etc., see Box 1 in Swinbank, 2017). The tariff bindings simply replicated those the UK had applied as an EU member state, giving other WTO Members little excuse to object to Brexitinduced changes, but rather oddly leaving the UK with tariff bindings denominated in euros. Earlier the UK had committed to maintaining existing access arrangements for developing countries under both the EBA (Everythingbut-Arms) scheme for the least-developed countries and the GSP (Generalised Scheme of Preferences) for most other developing countries (Department for International Trade, 2017).

WTO Members can, and often do, charge lower, applied, tariffs than the bound rates referred to above, provided they do so on a most-favoured-nation (MFN) basis. On 13 March 2019, with the initial date (29 March) for the UK's exit from the EU approaching, the UK Government announced the temporary MFN tariffs it was planning to apply in the event of a 'no-deal' Brexit. These, of course, would be charged on imports from the EU. The regime would be temporary, and 'would apply for up to 12 months while a full consultation and review on a permanent approach to tariffs is undertaken' (GOV.UK, 2019a). In a further significant move the Government announced that imports from Ireland into Northern Ireland, provided they are not transhipped to the rest of the UK, would be tariff free. On 8 
October 2019, after 'further discussions with industry and consumer groups', and 'having listened carefully to their feedback', this 'no-deal' tariff plan was updated (GOV.UK, 2019b).

The 'no-deal' tariff plan was a radical and dramatic move, as the proposal was to abolish, or slash, most tariffs at a stroke: the Government said that 88 per cent of the UK's imports by value would benefit from tariff-free access. The package was 'designed to minimise costs to business and consumers while protecting vulnerable industries'. Thus the exceptions (the remaining 12 per cent) included:

-'a mixture of tariffs and quotas on beef, lamb, pork, poultry and some dairy to support farmers and producers who have historically been protected through high EU tariffs';

- cars; but with duty-free imports of car parts 'to prevent disruption to supply chains';

- tariffs to 'help provide support for UK producers against unfair global trading practices', on ceramics, fertilisers and fuel;

- tariffs on 'bananas, raw cane sugar, and certain kinds of fish', to maintain 'preferential access to the UK market for developing countries' (UK.GOV, 2019a).

A post-Brexit Britain would also retain tariffs on cloves and vanilla, cocoa paste and butterfat, crude palm and coconut oil, fresh beans, rice, and rum. For rice two additional, autonomous (i.e. not bound in the UK's WTO Schedule), TRQs would be opened. For sugar - also of interest to developing countries - there would be a new autonomous TRQ for raw cane sugar for refining, which would operate in addition to existing concessions. Whilst the MFN tariff on raw cane sugar for refining would be retained, the tariff on white (refined) sugar would be reduced by over 60 per cent. This looks like a delicate balancing act, trying to reconcile the rather different interests of Tate \& Lyle Sugars, refining imported raw cane sugar, and British Sugar processing UK-grown sugar-beet, with Brazilian raw cane possibly displacing imports of EU white sugar from the market.

For lamb the existing MFN tariff would apply unchanged, although New Zealand would continue to have free entry to the UK market through its current TRQ. For other meats, a complex array of cuts in the MFN tariff and new, autonomous, TRQs would be introduced. Thus, for example, Ireland could hope to continue 
shipping some beef to the UK duty-free, although other suppliers that meet the UK's sanitary requirements (e.g. Australia) could compete to supply within these TRQ concessions.

The October 2019 update lowered the proposed 'no-deal' tariff on heavy goods vehicles, applied additional tariffs to some clothing items, and adjusted tariffs on bioethanol 'to retain support for UK producers'. The Government now declared that its 'no-deal' tariffs 'will mean lower prices in shops for consumers and the opportunity to source the best goods from around the world. For example, honey from New Zealand will see its tariff fall from 17\% to zero, grapes from Brazil will reduce from around 15\% to zero and other products, such as tennis rackets and wines will no longer face a tariff' (UK.GOV, 2019b).

On the date of the Government's initial announcement the National Farmers' Union (2019) published its own sober assessment of the tariff plan, treating it implicitly as a fait accompli. Later in the month the NFU and other UK farming unions in a letter to the Government wrote: 'We are keen to work with government to have a better understanding of the economic modelling, assumptions and potential trade-offs that have been used in arriving at this point. However, the underlying point is that a no-deal exit from the EU would be disastrous for British farming and food production and should be avoided at all costs. In the meantime, as there is still the possibility of a no-deal exit, government must act now to address these concerns and revise the tariffs and quotas accordingly, to try and lessen the significant damage which a no-deal would inflict on the UK farming sector'. The farm-focussed journal Farmers Weekly covered the story in its issue of 15 March 2019 under the headline 'Tariffs mess shows government policy is ill-considered', but there was no follow-up. Overall, there was little evidence of the outcry one might have expected from Copa-Cogeca (the main interest group representing EU farmers) had the EU made a similar unilateral move.

\section{The CAP's tariff barriers}

The CAP has undergone a number of significant 'reforms' since its first incarnation. Despite modest tariff cuts in the Uruguay Round, one unchanged 
feature of support for European agriculture is the prohibitively-high mostfavoured-nation (MFN) tariffs that are charged on a number of products (Swinbank, 2017). Although the EU indicated its willingness to countenance substantial cuts in border protection as part of a Single Undertaking (embracing the notion that nothing was agreed until everything had been agreed) in the stalled Doha Round, it has given no indication of its willingness to undertake unilateral cuts. A growing number of free trade agreements (FTAs), together with preferential access for developing countries, have partially opened the European market to cheaper agri-food imports. Moreover developed countries (Australia, New Zealand, the USA) also have access to limited import concessions through TRQs. In 2014 about 38 per cent by value of the EU's imports of agrifood products entered the EU under one of these preferential schemes (European Commission, 2015, Table 6). But attempts to extend these concessions weaken the protective effect of the EU's non-preferential trade barriers, and incur the wrath of the European farm lobby.

In June 2019, after two decades of negotiations, the EU agreed a FTA - yet to be ratified - with Mercosur, comprising Argentina, Brazil, Paraguay and Uruguay (European Commission, 2019). The agreement provides for GI (Geographical Indications) protection for $357 \mathrm{EU}$ food and drink products in Mercosur, and easier access for some food and drink products. In return, Mercosur gains increased access to EU markets, subject to TRQs. Copa-Cogeca immediately expressed 'deep regret' over the 'substantial concessions ... made in the agricultural chapter especially regarding some of the EU's most sensitive sectors, such as beef, poultry, sugar, ethanol, rice and orange juice ...' Given a 'huge difference in production standards', they claimed this would lead to 'unfair competition for some key European production sectors, putting their viability at stake' (Copa-Cogeca, 2019).

Apart from showing deference to farming interests, why might trade negotiators be reluctant to embrace unilateral liberalisation? In the early years of the Doha Round, with a Single Undertaking its declared objective, an argument that carried particular weight was that to reduce farm tariffs unilaterally would needlessly cast aside a valuable negotiating 'concession' that might form part of 
any 'deal' the EU could strike with countries seeking greater access to the EU's protected food markets. How salient this still is in the multilateral context, with the Doha Round more-or-less moribund, is an open question. However, the proposed FTA with Mercosur suggests that in bilateral negotiations the argument still carries weight: in future FTA negotiations with Australia, New Zealand and the USA, for example, tariff concessions on agri-food products could be 'traded' for more liberal access for EU goods and services to their markets. And as illustrated by the UK's 'no-deal' tariff schedule discussed earlier, another element in the political economy of the EU's agri-food trade strategy is the claim that high MFN tariffs offer significant advantages to developing countries that have preferential access to the EU's market, and that these benefits should be preserved in the longer term.

\section{Canadian reaction}

One ambition of Mrs May's government was to roll-over the EU's FTAs with countries around the world, so that the UK could continue to benefit from them. However, the announcement of its temporary 'no-deal' tariffs undercut the UK's ambitions. As the then Secretary of State, Liam Fox, admitted, Canada was reluctant to roll-over the EU-Canada agreement, as Canada believed it would benefit from largely tariff-free access to the UK under the 'no-deal' tariff schedule. Without a rollover of the FTA, British products would no longer have preferential access to the Canadian market. But Fox suggested the Canadians were misguided, emphasising 'that these are temporary tariffs'. If he had been a Canadian negotiator, he would want to lock into the market access advantages Canada currently enjoys on the British market for the longer term.

\section{WTO Considerations}

The plan to exempt exports from Ireland to Northern Ireland from import duties could be problematic, in that it seems to flout the WTO's most-favoured-nation principle by giving products from one source more favourable treatment than other MFN supplies. When asked about WTO compliance, the Government responded it was 'confident that the unique social, political and economic circumstances in Northern Ireland justify the temporary measures that the 
Government is taking, based on existing exceptions under WTO rules' (Written Question 238415, answered 8 April 2019). If 'temporary' really does mean '12 months or less', it may be that WTO Members will leave the measure unchallenged. If, in the event of a 'no-deal' Brexit, this measure is implemented, and 'temporary' begins to look more permanent, then a WTO challenge could be more likely. However, given the US-led embargo on replacing retired members of the Appellate Body, this may be an empty threat as the WTO's Dispute Settlement procedure could soon become inoperative.

\section{Exports to the EU}

The UK's tariff plans for a 'no-deal' Brexit are not contingent upon a reciprocal response from the EU. British exports to EU27 would face the latter's full MFN tariffs. In contrast to farmers' muted response to the tariff plan, noted above, the potential impact on export sales caused considerable concern, particularly among lamb producers in Wales. (This was no surprise: the particular problems confronting sheep producers were highlighted by Feng et al., 2017). Thus, in the hustings to succeed Mrs May, Jeremy Hunt's 10-point plan should he have become prime minister included a 'No Deal Relief Programme' that would 'include a $£ 6$ bn fund for the fishing and farming sectors who export to Europe to ease transition out of the European Union.' Six billion is an astonishing amount, although it is not clear whether this would have been additional money, or over how many years it would spread. For example, this can be compared to the UK's claim for an annual $€ 5.9$ billion allowance for amber box support, or to the $€ 3.3$ billion spent on CAP payments in the UK in 2018. Given this focus on the 'fishing and farming sectors who export to Europe', in what way would these payments differ from export subsidies that are no longer permissible under WTO rules?

\section{Mixed messages}

Recent developments send conflicting messages. Has the British Government's 'no-deal' tariff plan overturned the long-standing assumption that European farmers could successfully resist unilateral trade liberalisation, or is it simply the UK reasserting a consumer rather than producer orientation in farm policy? Whether a UK government would implement the 'no-deal' tariff plan was open to 
question. Would implementation of the plan make it easier or harder to negotiate FTAs with countries around the world, and close trade links with the EU? If 'nodeal' tariffs were to be implemented on a 'temporary' basis, how easy (politically and diplomatically) would it then be to reverse the deal and revert to the UK's tariff bindings? Contrariwise, if one UK politician was willing to spend $£ 6$ billion to support farmers and fishers, does that imply that agricultural exceptionalism is still a potent political force in British politics? Deal or no-deal, these debates are likely to reverberate for years to come.

\section{Further Reading}

Copa/Cogeca (2019). EU-Mercosur - Exiting Commission opens Pandora's box of double standards in agriculture. Press Release 28 June.

Department for International Trade (2017). Preparing for our future UK trade policy. Cm 9470. HMSO: London.

European Commission (2015). Distribution of EU agri-food imports by import regimes (2014). MAP 2015-2. European Commission: 2015.

European Commission (2019). EU and Mercosur reach agreement on trade. Press Release 28 June.

http://trade.ec.europa.eu/doclib/press/index.cfm?id=2039

Farmers Weekly, 170(26), 15 March 2019.

Feng, Siyi, Myles Patton, Julian Binfield \& John Davis (2017). 'Deal' or 'No Deal'? Impacts of Alternative Post-Brexit Trade Agreements on UK Agriculture.

EuroChoices, 16(3): 27-33

Fox, Liam (2019). Transcript of evidence to the International Trade Committee. 3 July. HC 436. House of Commons.

http://data.parliament.uk/writtenevidence/committeeevidence.svc/evidencedo cument/international-trade-committee/the-work-of-the-department-forinternational-trade/oral/103474.html

House of Commons (2019). Bills \& Legislation: https://services.parliament.uk/Bills/2019-

20/europeanunionwithdrawalagreement.html

Hunt, Jeremy (2019). My ten point plan for Brexit. https://www.facebook.com/notes/jeremy-hunt/my-ten-point-plan-forbrexit/1307362906077622/

GOV.UK (2019a). Temporary tariff regime for no deal Brexit published. 13 March. https://www.gov.uk/government/news/temporary-tariff-regime-for-nodeal-brexit-published

GOV.UK (2019b). Temporary tariff regime updated. https://www.gov.uk/government/news/temporary-tariff-regime-updated 
GOV.UK (2019c). New Protocol on Ireland/Northern Ireland and Political Declaration. https://www.gov.uk/government/publications/new-protocol-onirelandnorthern-ireland-and-political-declaration

National Farmers' Union (2019). UK applied Tariff Policy in event of no deal Brexit. NFU Briefing; and https://www.nfuonline.com/news/latest-news/nfureacts-to-no-deal-applied-tariffs-announcement/

Swinbank, Alan (2017). Brexit, Trade Agreements and CAP Reform. EuroChoices, 16(2): 4-9.

World Trade Organization (2019). Rectifications and Modifications of Schedules. Schedule XIX - United Kingdom. G/MA/TAR/RS/570. WTO: Geneva. The detailed schedule for agricultural products is available at:

https://assets.publishing.service.gov.uk/government/uploads/system/uploads/ attachment data/file/762822/UKs Goods Schedule at the WTO.pdf

\section{Summary}

In March 2019 the UK government published details of the import tariffs it planned to apply in the event of a 'no-deal' Brexit from the EU. Some 88 per cent of the UK's imports - including many agri-food products - would enter tarifffree. This proposed unilateral reduction in border protection promoted few protests from the UK's farm lobby, in marked contrast to the reaction voiced by EU farmers to the planned trade agreement with Mercosur. Trade diplomats are often loath to contemplate unilateral tariff cuts, as these could later form a crucial part of a bargain in multilateral or bilateral trade deals. Indeed, the UK's 'no-deal' tariff plan could undermine its objective of concluding ambitious Free Trade Agreements (FTAs) with the likes of Australia and the USA. Despite these developments in agri-trade policy, UK politicians continued to express concern about the viability of UK agriculture in a 'no-deal' scenario, and some promised to lavish tax-payer-funded support on the sector. Thus both free (or freer) trade and agricultural exceptionalism were canvassed cheek by jowl.

\section{Pull-quote}

It was a radical and dramatic move, as the proposal was to abolish, or slash, most tariffs at a stroke 


\section{Text to Accompany Photo \& Graphic}

Photo: Parliament Square, London, 19 October 2019 as Parliament sat and an estimated million people marched to demand a second referendum

Graphic: Tariff infographic, reproduced with the permission of the National Farmers' Union 